Bangladesh J. Plant Taxon. 13(1): 55-61, 2006 (June)

\title{
ETHNO-MEDICO-BOTANICAL KNOWLEDGE FROM KAUKHALI PROPER AND BETBUNIA OF RANGAMATI DISTRICT
}

\author{
Mohammed Yusuf, Md. Abdul Wahab, Jasim Uddin Chowdhury \\ AND JARIPA BEGUM \\ BCSIR Laboratories, P.O. Chittagong Cantonment, Chittagong-4220, Bangladesh \\ Key words: Ethno-medico-botany, Kaukhali, Betbunia, Rangamati
}

\begin{abstract}
A survey was carried out between July 2001 and June 2002 in Kaukhali proper and Betbunia area of Rangamati district to document the medicinal plants of that area and their uses. During this work 34 species representing 23 genera and 17 families were found, which are used by the Chakma and Marma tribes and the Bangalis living there for the treatment of 31 diseases. Botanical and tribal names of the plants, parts used, name of the diseases, and name of the users have been mentioned.
\end{abstract}

\section{Introduction}

Kaukhali proper is about $10 \mathrm{~km}$ west to Rangamati town. Betbunia is a Union under Kaukhali P.S. situated about 9 km south of Kaukhali proper and about 18 km south-west to Rangamati town. Being a hilly area they are rich in floral diversity. Inhabitants of those areas are mostly tribal, dominated by Chakma and Marma. Many of them still depend on local medicinal plants for the treatment of different diseases. A good number of Bangali families are also living there. They also use quite a good number of medicinal plants for the treatment of different diseases. In recent years due to development of good communication, modern doctors and medicines have reached there, resulting decline in the use of traditional medicine. Therefore the knowledge of traditional use of medicinal plants by the local people is likely to be lost in near future, and for this it is necessary to document as much as possible the existing available information.

Only a limited work has been done on the tribal folk medicine in the Chittagong HillTracts i.e., Alam 1992, Chakma, et al. 2003, Rahman et al. 1998; Rahman and Uddin 1998, Rahman 2003, Uddin 2001, Yusuf et al. 2002. Keeping this in mind this survey was done to document those valuable ethno-medico-botanical knowledge. The survey was carried out for about a year. During this work 34 species representing 23 genera and 17 families were documented which are used for the treatment of 31 diseases. Local names of those plants, parts used, method of use and doses are mentioned. 


\section{Materials and Methods}

Uses of medicinal plants have been documented on ethnobotanical data sheet by interviewing tribal healers and elderly people of the study areas, namely, Kaukhali and Betbunia. The study was made for about one year, between July 2001 and June 2002 by repeatedly visiting the areas in different seasons to get the information on the plants. The information were verified by repeated inquiries and asking the tribal healers as far as possible. The voucher specimens of most of the species have been collected, identified and preserved in the herbarium of BCSIR Laboratories, Chittagong. Plants are arranged alphabetically by their botanical names followed by tribal names, family names and voucher number. In case of most common and well-known plants voucher number has not been mentioned.

\section{Results and Discussion}

Data collected on the uses of medicinal plants by the tribes and Bangali of the study areas are given below in the tabular form (Table 1)

Uses of the following 18 plants described above viz., Abrus sp., Alocasia cuculata, Alstonia scholaris, Asparagus acerosus, Boreria articularies, Clerodendrum indicum, Costus speciosus, Desmodium triquetrum, Pavetta sp. Leucas zeylanica, Leucas aspera, Mitracarpus hirtus, Ocimum americanum (citral type), Plumbago zeylanica, Pouzolzia zeylanica, Scoparia dulcis, Sida orientalis, Synedrilla nodiflora do not match with the reports consulted. Probably the usage is new so far known. Additional uses along with the reported one was documented in case of Achyranthes aspera, Acorus calamus, Amaranthus spinosus and Rauvolfia serpentina (Kirtiker and Basu1975, Alam et al. 1996, Khan et al. 2002, Chakma et al. 2003).

In case of Cassia fistula same use was reported for bark and wood (Kirtiker 1975) instead of fruit pulp as recorded here. Marma tribe uses the root of Plumbago zeylanica in case of suppression of menses. It has a rational basis, because "plumbagin" contained in the root has stimulant effect on muscular tissue of uterus and on nervous system (Kirtikar and Basu 1975). It was observed during the investigation that tribal of Betbunia and Kaukhali generally use single plant for the preparation of medicine, rarely two or more than two plants. But the Bangalis in Kaukhali were found to use a number of plants instead of single plant. Moreover, they use some minerals also, which was not found in tribal preparations. Probably this is due to the influence of Ayurvedic and Unani systems of medicine on them. The local people reported during the investigations that the number of tribal practitioners has declined to only a few now-a-days than in the past. 
Table 1. Ethno-medico-botanical data from Kaukhali proper and Betbunia of Rangamati.

\begin{tabular}{|c|c|c|c|c|}
\hline $\begin{array}{l}\text { Scientific name, family } \\
\text { name, voucher number }\end{array}$ & Local name & Locality & Diseases & Uses \\
\hline $\begin{array}{l}\text { Abrus precatorious L. } \\
\text { (Leguminosae) } \\
\text { Voucher No. } 1190\end{array}$ & $\begin{array}{l}\text { Bengali.- } \\
\text { Kunch, Rati, } \\
\text { Jostimadhu }\end{array}$ & Kaukhali & Gastric pain & $\begin{array}{l}\text { Dry roots of this plant along with the dry leaves of Coccinea cordifolia, } \\
\text { Cassia angustifolia and whole herb of Ipomea quamoclit, Cleome viscosa } \\
\text { and Clitoria ternatea are pounded together and pills (size of a small } \\
\text { marble) made from this is given orally. Dose: } 1 \text { tablet daily in the } \\
\text { morning with water (Users: Bangali). }\end{array}$ \\
\hline $\begin{array}{l}\text { Abrus sp. (Leguminosae) } \\
\text { Voucher No. } 1098\end{array}$ & $\begin{array}{l}\text { Marma- } \\
\text { Yattaripru }\end{array}$ & Betbunia & $\begin{array}{l}\text { Urinary } \\
\text { arrest/ } \\
\text { Oliguria }\end{array}$ & $\begin{array}{l}\text { Root paste mixed with rice-socked water is prescribed orally. Dose: } 1 \text { cup } \\
\text { twice daily for } 3 \text { days (Users: Marma). }\end{array}$ \\
\hline $\begin{array}{l}\text { Achyranthes aspera L. } \\
\text { (Amaranthaceae) }\end{array}$ & $\begin{array}{l}\text { Marma- } \\
\text { Chainchi }\end{array}$ & Betbunia & $\begin{array}{l}\text { Impotency, } \\
\text { Jaundice, } \\
\text { Dropsy }\end{array}$ & $\begin{array}{l}\text { Root paste is given orally with honey for impotency. Dose: } 1 \text { teaspoonful } \\
\text { once daily for } 3-4 \text { days. In jaundice and dropsy, necklets made of root } \\
\text { pieces worn on head and kept till cure (Users: Marma). }\end{array}$ \\
\hline $\begin{array}{l}\text { Acorus calamus L. (Araceae) } \\
\text { Voucher No.1106 }\end{array}$ & $\begin{array}{l}\text { Marma- } \\
\text { Laonochi }\end{array}$ & Betbunia & $\begin{array}{l}\text { Paralysis, } \\
\text { Epileptic faint }\end{array}$ & $\begin{array}{l}\text { Rhizome paste along with the bile of Python and fruits of Myristica } \\
\text { fragrans is rubbed on the affected parts in paralysis. Bruised leaves are } \\
\text { put before nose of the patient of epilepsy for relief (Users: Marma). }\end{array}$ \\
\hline $\begin{array}{l}\text { Albizia procera Benth. } \\
\text { (Leguminosae) }\end{array}$ & $\begin{array}{l}\text { Chakma- } \\
\text { Sadakoroi }\end{array}$ & Betbunia & Thread worm & $\begin{array}{l}\text { Fresh leaves or paste of the young leaves are prescribed orally along with } \\
\text { rice. Dose: Teaspoonful of paste twice daily for 2-3 days (Users: } \\
\text { Chakma). }\end{array}$ \\
\hline $\begin{array}{l}\text { Allium sativum L. } \\
\text { (Liliaceae) }\end{array}$ & $\begin{array}{l}\text { Chakma- } \\
\text { Rasun }\end{array}$ & Betbunia & $\begin{array}{l}\text { Localized } \\
\text { baldness } \\
\text { (Alopecia) }\end{array}$ & $\begin{array}{l}\text { Blood of Monopterous cuchia is applied over head after cleaning and } \\
\text { then paste of garlic is applied along with the jhul i.e., spider net along } \\
\text { with dirt (Users: Chakma). }\end{array}$ \\
\hline $\begin{array}{l}\text { Alocassia cuculata Schott.( } \\
\text { Araceae) Voucher No. } 1104\end{array}$ & $\begin{array}{l}\text { Marma- } \\
\text { Sapposraku }\end{array}$ & Betbunia & $\begin{array}{l}\text { Hardness of } \\
\text { Abdomen } \\
\text { (Peterdhola) }\end{array}$ & $\begin{array}{l}\text { Rhizome paste is swallowed along with ripe banana. Dose: About a } \\
\text { tablespoonful once daily for } 2-3 \text { days (Users: Marma). }\end{array}$ \\
\hline $\begin{array}{l}\text { Alstonia scholaris (L.) R.Br. } \\
\text { (Apocynaceae) } \\
\text { Voucher No. } 1100\end{array}$ & $\begin{array}{l}\text { Marma- } \\
\text { Chailoi }\end{array}$ & Betbunia & Arthritic pain & $\begin{array}{l}\text { Leaf paste is warmed and applied as a poultice twice daily over affected } \\
\text { parts. (Users: Marma). }\end{array}$ \\
\hline $\begin{array}{l}\text { Amaranthus spinosus L. } \\
\text { ( Amaranthaceae) }\end{array}$ & $\begin{array}{l}\text { Chakma- } \\
\text { Kata marish }\end{array}$ & Betbunia & $\begin{array}{l}\text { Fever and } \\
\text { Ranikhet } \\
\text { disease in } \\
\text { chicken }\end{array}$ & $\begin{array}{l}\text { Root extract along with the fruit of Myristica fragrens is given in fever } \\
\text { along with rice soaked water. Dose: Half glass twice daily for three days. } \\
\text { Infant dose is half. In ranikhet of chicken root juice mixed with boiled } \\
\text { rice and cow dung is prescribed. Dose: Half teaspoon 2-3 times a day } \\
\text { (Users: Chakma). }\end{array}$ \\
\hline
\end{tabular}




\begin{tabular}{|c|c|c|c|c|}
\hline $\begin{array}{l}\text { Scientific name, family } \\
\text { name, voucher number }\end{array}$ & Local name & Locality & Diseases & Uses \\
\hline $\begin{array}{l}\text { Asparagus acerosus Roxb. } \\
\text { (Liliaceae) } \\
\text { Voucher no. } 1097\end{array}$ & $\begin{array}{l}\text { Marma- } \\
\text { Saktichara, } \\
\text { Chulanopay }\end{array}$ & Betbunia & $\begin{array}{l}\text { Arthritis, } \\
\text { leucorrhoea, } \\
\text { abdominal } \\
\text { pain }\end{array}$ & $\begin{array}{l}\text { Paste of the roots along with other ingredients is given orally. Dose: One } \\
\text { teaspoon twice daily for a week for arthritis and leucorrhoea and one table } \\
\text { spoon twice for one day in abdominal pain (Users: Marma). }\end{array}$ \\
\hline $\begin{array}{l}\text { Borreria articularies (L.f.) } \\
\text { F.N.Will. } \\
\text { ( Rubiaceae) } \\
\text { Voucher no. } 1162\end{array}$ & $\begin{array}{l}\text { Bengali - } \\
\text { Ekdaira }\end{array}$ & Kaukhali & Bronchitis & $\begin{array}{l}\text { Dried leaves of this plant along with the leaves of Nyctanthes arbortristis } \\
\text { is grind together and tablet (size of a pea) made and given orally. Dose: } 1 \\
\text { tablet twice daily for } 15 \text { days (Users: Bangali). }\end{array}$ \\
\hline $\begin{array}{l}\text { Cassia alata } \mathrm{L} . \\
\text { (Leguminosae) }\end{array}$ & $\begin{array}{l}\text { Chakma- } \\
\text { Dadgach }\end{array}$ & Betbunia & Thread worm & $\begin{array}{l}\text { Decoction of the leaves is prescribed orally before meal at night. Dose: } \\
\text { One glassful for } 2 \text { days (Users: Chakma). }\end{array}$ \\
\hline $\begin{array}{l}\text { C. fistula L. } \\
\text { (Leguminosae) }\end{array}$ & $\begin{array}{l}\text { Marma- } \\
\text { Miaopiga }\end{array}$ & Betbunia & Dysentery & $\begin{array}{l}\text { Inner portion of the young fruit is prescribed orally. Dose: Small amount } \\
\text { (5-6 gms) twice daily for a week (Users: Marma). }\end{array}$ \\
\hline $\begin{array}{l}\text { C. occidentalis L. } \\
\text { (Leguminosae) } \\
\text { Voucher No. } 1101\end{array}$ & Marma- Kajor & Betbunia & $\begin{array}{l}\text { Respiratory } \\
\text { problem }\end{array}$ & $\begin{array}{l}\text { Decoction of the leaves is prescribed orally. Dose: Half cup of decoction } \\
\text { twice daily for 2-3 days (Users: Marma). }\end{array}$ \\
\hline $\begin{array}{l}\text { Clerodendrum indicum (L.) } \\
\text { Kuntze. } \\
\text { (Verbenaceae) } \\
\text { Voucher No. } 1196\end{array}$ & $\begin{array}{l}\text { Bengali- } \\
\text { Ekdaira gach }\end{array}$ & Kaukhali & Carbuncle & $\begin{array}{l}\text { Leaves of the plants along with the whole herb of Commelina diffusa, } \\
\text { Cynodon dactylon and Plumbago indica is made into paste and applied } \\
\text { over the carbuncle. It is applied after washing with warm water and } \\
\text { continues for a week (Users: Bangali). }\end{array}$ \\
\hline $\begin{array}{l}\text { C. viscosum L. } \\
\text { (Verbenaceae) } \\
\text { Voucher No. } 1096\end{array}$ & $\begin{array}{l}\text { Marma- } \\
\text { Vegach }\end{array}$ & Betbunia & $\begin{array}{l}\text { poisonous } \\
\text { insect bite }\end{array}$ & $\begin{array}{l}\text { Paste of few young leaves is applied as a poultice on the affected area } \\
\text { (Users: Marma). }\end{array}$ \\
\hline $\begin{array}{l}\text { Costus speciosus (Koinig) } \\
\text { Sm. (Costaceae) }\end{array}$ & $\begin{array}{l}\text { Marma- } \\
\text { Kedogi }\end{array}$ & Betbunia & Pus in ear & $\begin{array}{l}\text { Juice of the roasted stem of the plant is squeezed out and given as a drop } \\
\text { in ear. Dose: few drops 2-3 times a day for three days (Users: Marma). }\end{array}$ \\
\hline $\begin{array}{l}\text { Cyathula prostrata } \mathrm{Bl} \text {. } \\
\text { (Amaranthaceae) Voucher } \\
\text { no. } 1086,1163\end{array}$ & $\begin{array}{l}\text { Chakma \& } \\
\text { Bangali - } \\
\text { Uphutlengra }\end{array}$ & $\begin{array}{l}\text { Betbunia } \\
\text { and } \\
\text { Kaukhali }\end{array}$ & $\begin{array}{l}\text { Urinary } \\
\text { calculi, } \\
\text { Headache }\end{array}$ & $\begin{array}{l}\text { In Betbunia, red iron dipped in to the juice of the root and the juice is } \\
\text { prescribed orally for urinary calculi. Dose: Half cup of juice twice daily. } \\
\text { In primary stage } 3 \text { doses only. In Kaukhali garland made from the root } \\
\text { pieces is tie on head to get relief from headache (Users: Chakma \& } \\
\text { Bangali). }\end{array}$ \\
\hline
\end{tabular}




\begin{tabular}{|c|c|c|c|c|}
\hline $\begin{array}{l}\text { Scientific name, family } \\
\text { name, voucher number }\end{array}$ & Local name & Locality & Diseases & Uses \\
\hline $\begin{array}{l}\text { Desmodium triquetrum DC. } \\
\text { (Leguminosae) } \\
\text { Voucher no. } 1092\end{array}$ & $\begin{array}{l}\text { Marma- } \\
\text { Pha loy joy }\end{array}$ & Betbunia & $\begin{array}{l}\text { Threadworm, } \\
\text { bleeding piles }\end{array}$ & $\begin{array}{l}\text { Decoction of the fresh leaves is prescribed orally. Dose: } 2 \text { teaspoon 2-3 } \\
\text { times a day for 2-3 days in both the cases (Users: Marma). }\end{array}$ \\
\hline $\begin{array}{l}\text { Holarrhena pubescens } \\
\text { (Buch.- Ham.)Wall. } \\
\text { (Apocynaceae) }\end{array}$ & $\begin{array}{l}\text { Chakma- } \\
\text { Kuruch }\end{array}$ & Betbunia & Dysentery & $\begin{array}{l}\text { Paste of the bark is prescribed along with curd. Dose: } 1 \text { table spoon twice } \\
\text { daily for three days (Users: Chakma). }\end{array}$ \\
\hline $\begin{array}{l}\text { Kaempferia parviflora L. } \\
\text { (Zingiberaceae) } \\
\text { Voucher no. } 1089\end{array}$ & $\begin{array}{l}\text { Chakma- } \\
\text { Kala halud }\end{array}$ & Betbunia & $\begin{array}{l}\text { Poisonous } \\
\text { insect bite }\end{array}$ & Paste of the rhizome and leaf is applied as poultice on bite area. \\
\hline $\begin{array}{l}\text { K. rotunda L. } \\
\text { (Zingiberaceae) Voucher no. } \\
1105\end{array}$ & $\begin{array}{l}\text { Marma- } \\
\text { Bhujuraphul }\end{array}$ & Betbunia & $\begin{array}{l}\text { Scabies, } \\
\text { wound }\end{array}$ & $\begin{array}{l}\text { Paste of the rhizome along with some other ingredients (untoled) is } \\
\text { applied as a poultice. It is applied once daily for a week. }\end{array}$ \\
\hline $\begin{array}{l}\text { Leucas aspera (Willd.) Link. } \\
\text { (Lamiaceae) } \\
\text { Voucher no. } 1164\end{array}$ & $\begin{array}{l}\text { Bengali - } \\
\text { Shetadron, } \\
\text { Donkalash }\end{array}$ & Kaukhali & $\begin{array}{l}\text { Earache, } \\
\text { arthritic pain }\end{array}$ & $\begin{array}{l}\text { Slightly wormed leaf juice is pour into ear to cure earache. For arthritic } \\
\text { pain leaves are cooked and taken as vegetables. }\end{array}$ \\
\hline $\begin{array}{l}\text { L. zeylanica (L.) R.Br. } \\
\text { (Lamiaceae) } \\
\text { Voucher no. } 1095\end{array}$ & $\begin{array}{l}\text { Marma- } \\
\text { Paichangcha }\end{array}$ & Betbunia & $\begin{array}{l}\text { Convulsion } \\
\text { due to fever }\end{array}$ & $\begin{array}{l}\text { Necklet made with the pieces of roots are tie on arms and legs and kept } \\
\text { till cures. }\end{array}$ \\
\hline $\begin{array}{l}\text { Melia sempervirens (L.) All. } \\
\text { (Meliaceae) Voucher no. } \\
1157\end{array}$ & $\begin{array}{l}\text { Bengali - } \\
\text { Ghoranim }\end{array}$ & Kaukhali & Skin disease & $\begin{array}{l}\text { Leaf paste of this plant along with camphor, copper sulfate, alum and } \\
\text { borax is applied superficially. It is applied twice daily until cure. }\end{array}$ \\
\hline $\begin{array}{l}\text { Mitracarpus hirtus } \\
\text { (Rubiaceae) } \\
\text { Voucher no. } 1161\end{array}$ & $\begin{array}{l}\text { Bengali - } \\
\text { Padmamukhi }\end{array}$ & Kaukhali & $\begin{array}{l}\text { Blood } \\
\text { dysentery }\end{array}$ & $\begin{array}{l}\text { Dried herb, dried mango seed kernel, dried green fruit of Aegle mermelos } \\
\text { and fruits of Terminalia balerica is grind together and tablet (size of a } \\
\text { pea) made from the powder is prescribed orally. Dose: } 2 \text { tablets thrice } \\
\text { daily for } 5 \text { days. }\end{array}$ \\
\hline $\begin{array}{l}\text { Ocimum americanum L.- } \\
\text { Camphor type (Lamiaceae) } \\
\text { Voucher no. } 1159\end{array}$ & $\begin{array}{l}\text { Bengali - } \\
\text { Tulsi }\end{array}$ & Kaukhali & Cataract & $\begin{array}{l}\text { Juice of this plant along with Ludwigia hyssopifolia is given in eye as a } \\
\text { drop. Dose: Two drops thrice daily for 7-8 days. }\end{array}$ \\
\hline
\end{tabular}




\begin{tabular}{|c|c|c|c|c|}
\hline $\begin{array}{l}\text { Scientific name, family } \\
\text { name, voucher number }\end{array}$ & Local name & Locality & Diseases & Uses \\
\hline $\begin{array}{l}\text { Ocimum americanum L.- } \\
\text { Citral type (Lamiaceae) } \\
\text { Voucher no. } 1090\end{array}$ & $\begin{array}{l}\text { Chakma- } \\
\text { Sabrang }\end{array}$ & Betbunia & $\begin{array}{l}\text { Eye disease of } \\
\text { chicken }\end{array}$ & Leaves rubbed on eyelids 2-3 times daily for 4-5 days. \\
\hline $\begin{array}{l}\text { Pavetta sp. } \\
\text { (Rubiaceae) } \\
\text { Voucher no. } 1102\end{array}$ & $\begin{array}{l}\text { Marma- } \\
\text { Sangraimay }\end{array}$ & Betbunia & $\begin{array}{l}\text { Menstrual } \\
\text { irregularity }\end{array}$ & $\begin{array}{l}\text { Root paste of this plant along with the root of Clerodendrum viscosum } \\
\text { and Plumbago zeylanica is prescribed orally. Dose: } 1 \text { tablespoonful 2-3 } \\
\text { times a day for a week. }\end{array}$ \\
\hline $\begin{array}{l}\text { Plumbago zeylanica } \mathrm{L} \text {. } \\
\text { (Plumbaginaceae) Voucher } \\
\text { no.1099 }\end{array}$ & $\begin{array}{l}\text { Marma- } \\
\text { Kaincho apru }\end{array}$ & Betbunia & $\begin{array}{l}\text { Suppression } \\
\text { of menses }\end{array}$ & $\begin{array}{l}\text { Paste of the root along with the root of Clerodendrum viscosum is } \\
\text { prescribed orally. Dose: About a tablespoonful once daily for 2-3 days. }\end{array}$ \\
\hline $\begin{array}{l}\text { Pouzolzia zeylanica (L.) } \\
\text { Benn. (Urticaceae) }\end{array}$ & $\begin{array}{l}\text { Chakma- } \\
\text { Biskatali }\end{array}$ & Betbunia & Pustules & $\begin{array}{l}\text { Paste made from the leaves of this plant along with the leaves of Sida } \\
\text { rhombifolia is applied as a poultice over pustules to hasten suppuration. }\end{array}$ \\
\hline $\begin{array}{l}\text { Rauvolfia serpentina (L.) } \\
\text { Benth.ex Kurz. } \\
\text { (Apocynaceae) } \\
\text { Voucher no. } 1093\end{array}$ & $\begin{array}{l}\text { Chakma- } \\
\text { Surchan }\end{array}$ & Betbunia & $\begin{array}{l}\text { High blood } \\
\text { pressure, } \\
\text { respiratory } \\
\text { problem }\end{array}$ & $\begin{array}{l}\text { Fresh root juice or dried root powder soaked in water is prescribed orally. } \\
\text { Dose: } 1 \text { teaspoonful twice daily. }\end{array}$ \\
\hline $\begin{array}{l}\text { Scoparia dulcis L. } \\
\text { (Scrophulariaceae) } \\
\text { Voucher no. } 1165\end{array}$ & $\begin{array}{l}\text { Bengali - } \\
\text { Bondhoinna }\end{array}$ & Kaukhali & Jaundice & $\begin{array}{l}\text { Tablet (size of a pea) made from the whole plant along with cardamom, } \\
\text { black pepper and borax are prescribed orally. Dose: } 2 \text { tablet twice daily } \\
\text { for } 2 \text { weeks. }\end{array}$ \\
\hline $\begin{array}{l}\text { Sida orientalis Cav. } \\
\text { (Malvaceae) } \\
\text { Voucher No. } 1167\end{array}$ & $\begin{array}{l}\text { Bengali - } \\
\text { Bailodi }\end{array}$ & Kaukhali & $\begin{array}{l}\text { Tumor in the } \\
\text { uterus }\end{array}$ & $\begin{array}{l}\text { Tablet ( size of a marble) made from the leaves of this plant along with } \\
\text { the leaves of Melochia chorchorifolia, Ludwigia hyssopifolia and the } \\
\text { flower of Nelumbo nucifera are prescribed orally. Dose: } 2 \text { tablet daily } \\
\text { until cure. }\end{array}$ \\
\hline $\begin{array}{l}\text { Synedrilla nodiflora Gaertn. } \\
\text { (Asteraceae) } \\
\text { Voucher no.1094 }\end{array}$ & $\begin{array}{l}\text { Marma- } \\
\text { Ochonsagor } \\
\text { biai }\end{array}$ & Betbunia & Scabies & $\begin{array}{l}\text { Water boiled along with the leaves of this plant is used as a bath for seven } \\
\text { days. }\end{array}$ \\
\hline $\begin{array}{l}\text { Tagetis erecta L. } \\
\text { (Asteraceae) }\end{array}$ & $\begin{array}{l}\text { Bengali- } \\
\text { Genda }\end{array}$ & Kaukhali & Piles & $\begin{array}{l}\text { Leaves of this plant are pounded along with the fruits of Phyllanthus } \\
\text { emblica, Terminalia chebula, T. belerica and roots of Glycirhyza glabra } \\
\text { and the juice is expressed out. This juice is given orally in piles. Dose: } 1-2 \\
\text { tablespoonful once daily for } 20-21 \text { days. }\end{array}$ \\
\hline $\begin{array}{l}\text { Zingiber montanum (Koenig) } \\
\text { A.Dietr. (Zingiberaceae) }\end{array}$ & Marma- Paley & Betbunia & Flatulance & Rhizome paste is prescribed orally. Dose: 1 teaspoon $2-3$ times a day. \\
\hline
\end{tabular}




\section{Acknowledgement}

The authors are grateful to the Ministry of Science and Technology, Government of the Peoples Republic of Bangladesh, for providing financial support to carry out this investigation. Thanks are also due to the Director, BCSIR Laboratories, Chittagong for his generous co-operation and encouragement during the work.

\section{References}

Alam, M. K. 1992. Medical ethnobotany of the Marma Tribe of Bangladesh. Economic Botany 46(3): 330335.

Alam, M. K., Choudhury, J. and Hassan, M.A. 1996. Some folk formularies from Bangladesh. Bangladesh J. life Sci. 8(1)49-63.

Chakma, S., Hossain, M.K., Khan, B.M. and Kabir, M.A. 2003. Ethno-botanical knowledge of Chakma community in the use of medicinal plants in Chittagong Hill Tracts, Bangladesh. MFP News, XIII(3) : 3-7. Dehra Dun, India.

Khan, M.S., Hassan, M.A. and Uddin, M.Z. 2002. Ethnobotanical survey in Rema-Kalenga Wildlife Sanctuary (Habiganj) in Bangladesh. Bangladesh J. Plant Taxon. 9(1) : 51-60.

Kirtikar, K.R. and Basu, B.D. reprint 1975. Indian medicinal plants Vol. I-IV. Bishen Singh Mahendra Pal Singh, New Connaught Place, Dehrahun.

Rahman, M.A., 2003. Ethno-medico-botanical knowledge among tribals of Bangladesh. In: Ethnobotany and Medicinal Plants of Indian Subcontinent. Scientific Publisher, Jodhpur, India pp. 89-93.

Rahman, M.A., and Uddin, S.B. 1998. Some anti-rheumatic plants used by tribal people of the Hill tracts districts. Biodiversity Newsletter, University of Chittagong 2(2): 4.

Rahman, M.A., Uddin, S.B. and Khisha, A. 1998. A report on some anti-jaundice plants from tribal community of Hill tracts districts. Biodiversity Newsletter, University of Chittagong 2(1): 4.

Uddin, S.B. 2001. A comparative ethnobotanical study among the tribal communities of Chittagong HillTracts. Bangladesh. Ph.D. thesis submitted to the University of Aberdeen.

Yusuf, M., Rahman, M..A., Chowdhury, J.U. and Begum, J. 2002. Indigenous knowledge about the use of Zingibers in Bangladesh. J.Econ. Taxon. Bot. 26(3): 566-570. 